\title{
Review Article \\ Tectonic Control on Drainage Network Evolution in the Upper Narmada Valley: Implication to Neotectonics
}

\author{
Girish Ch. Kothyari and B. K. Rastogi \\ Institute of Seismological Research, Raisan, Gandhinagar, Gujarat 382 009, India \\ Correspondence should be addressed to Girish Ch. Kothyari; kothyarigirish_k@rediffmail.com
}

Received 15 May 2013; Revised 12 August 2013; Accepted 17 August 2013

Academic Editor: Biswajeet Pradhan

Copyright (c) 2013 G. Ch. Kothyari and B. K. Rastogi. This is an open access article distributed under the Creative Commons Attribution License, which permits unrestricted use, distribution, and reproduction in any medium, provided the original work is properly cited.

\begin{abstract}
Convergence of the Indian plate towards Eurasia is reflected in neotectonics along several zones throughout the Indian plate. Neotectonics of the upper Narmada river basin following one of the active Son-Narmada Fault (SNF central part) zones in central Peninsular India has been studied through tectonic geomorphometric parameters. The study area is $175 \mathrm{~km}$ wide and $400 \mathrm{~km}$ long valley and catchment area of upper Narmada river basin in Madhya Pradesh state. High resolution ASTER data indicates neotectonic features like sudden changes in drop of Narmada river floor at two locations around Jabalpur formed by conjugate normal faults. Cross profiles indicate uplift of the entire area by a few hundred meters south of the Son-Narmada south fault. Basin asymmetry parameter indicates northward shifting of the river course from middle of the basin due to uplift of the southern block.
\end{abstract}

\section{Introduction}

Cratonic part of central India has witnessed reactivation during Precambrian. Later during Cretaceous, a $\sim 1600 \mathrm{~km}$ long and $200 \mathrm{~km}$ wide ENE-WSW trending rift zone developed in central Indian peninsula [1]. Three pericontinental rift basins were formed in the western margin of the Indian shield. The Son-Narmada rift developed in parallel to the Satpura trend during late Cretaceous, while the Cambay graben formed in colinearity with the Dharwar trend during early Cretaceous [2]. The Son-Narmada fault (SNF) zone has a Precambrian ancestry which separates Vindhyan basin to its north and the Gondwana belt southwards [3]. In both northern and southern regions of the Son-Narmada lineament, vertical block movements have been reported $[3,4]$. Due to these movements, the Bijawar group of rocks within the SNF zone got uplifted during the time of sedimentation in Vindhyan Supergroup [5]. Presence of series of ENE-WSW trending subsurface structures within the sediments of Cambay basin suggests extension of Satpura trend across the basin. The NESW Aravalli-Delhi trend is well reflected in northern part of Cambay basin $[2,6]$. Faults and lineaments are mainly aligned parallel/subparallel to the major tectonic grains. Along the marginal faults of Cambay basin, the Deccan Traps have been downfaulted (3000-5000 m); throw being more in eastern marginal fault has resulted in asymmetric graben structure [7-10]. The Son-Narmada fault/lineament and Tapi north Fault have ENE-WSW trend and control the course of main drainage system [11]. The Son-NarmadaTapi (SONATA) zone extends WNW up to the shore of the Arabian Sea. Represented by a fault pair, SONATA defines Narmada rift valley and Satpura horst. Tapi Fault marks the southern boundary of the Satpura range and northern boundary of Tapi alluvium. Several hot springs are reported in close proximity of this fault zone. Important lineaments present in this area include West Coast, JaisalmerBarwani, Rikhabdev, Chambal-Jamnagar, Kishangarh-Chipri (NE corner of Figure 1), and Pisangan-Vadnagar lineaments [2] (Figures 1(a) and 1(b)). The SNF zone divides the Indian plate into two halves and has a long tectonic history dating back to the Archaean time, trending ENE-WSW. Both Narmada and Tapi rivers all through their courses follow these tectonic trends (Figures 1(a) and 1(b)). Geophysical studies in the SNF zone reveal that this is a zone of intense deep seated faulting which reactivated around 2.5-2.2 and 1.5-0.9 Ga [12]. The faults dip steeply by $70^{\circ}-80^{\circ}$ [13]. The throw of the faults 


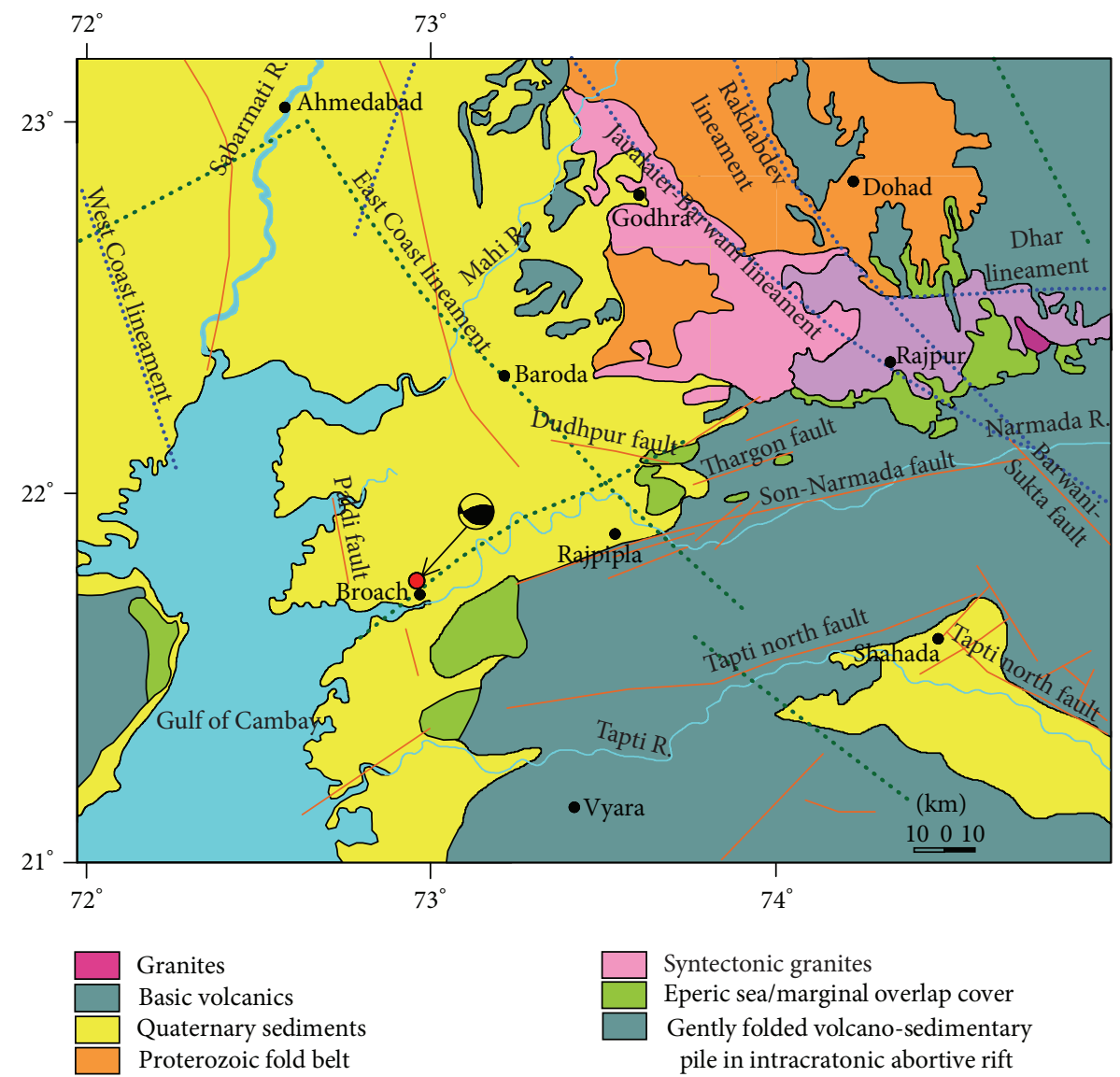

(a)

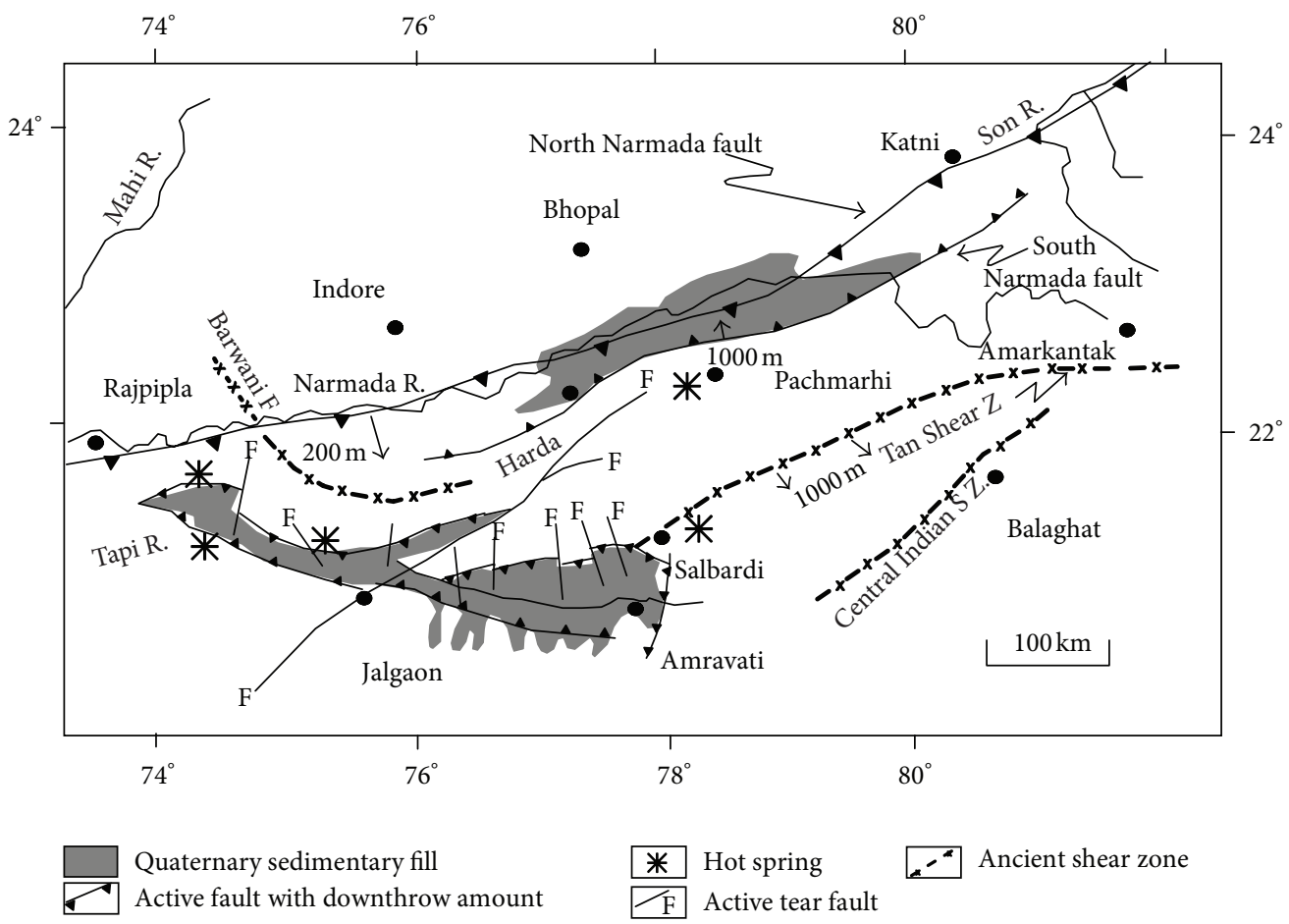

(b)

Figure 1: (a) Geological map of Narmada river valley shows major lineaments in the area [2]. (b) Map shows active grabens, the Narmada graben in the north, and Tapi graben in the south $[15,23]$. Elevations of a few points are given. 


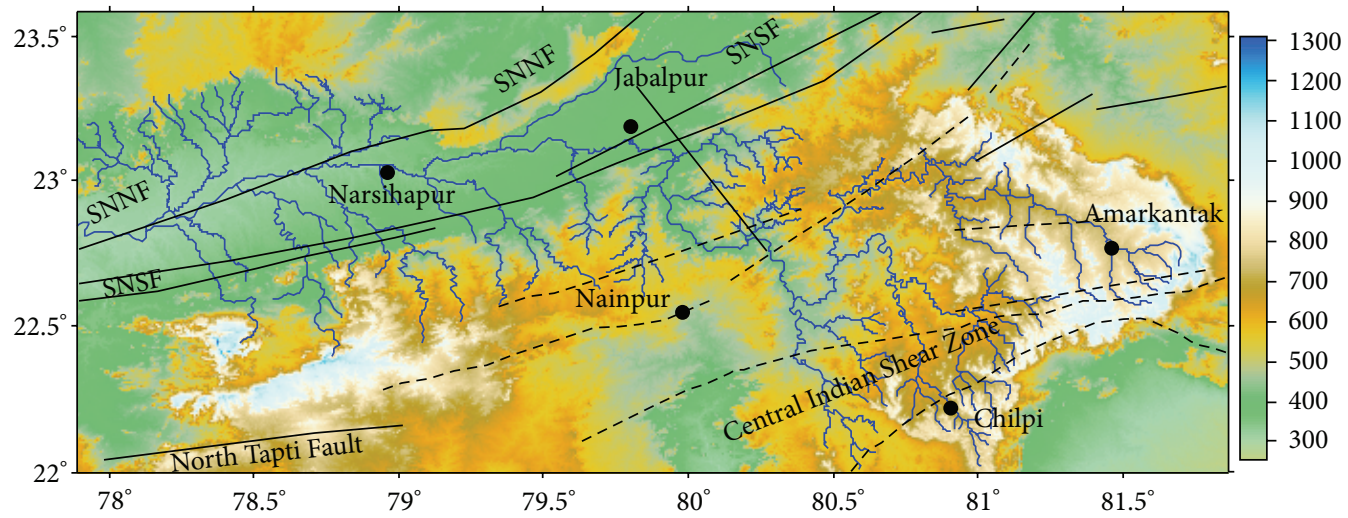

Figure 2: Digital elevation model (DEM) of upper Narmada valley, showing development of major landforms and position of major faults controlling the drainage basin. SNNF is Son-Narmada north fault, and SNSF is Son-Narmada south fault.

is of the order of 1500 to $1800 \mathrm{~m}$ [14]. The Narmada graben is displaced by $20-30 \mathrm{~m}$ along multiplicity of transverse tear faults. Pleistocene sedimentary terraces in SNF zone are tilted $20-25^{\circ}$ in the tract Hardi-Jabalpur and are also displaced 10$15 \mathrm{~m}$ near Navagram [15]. The seismic structure and existence of sedimentary basin of SONATA zone is interpreted by Murty et al. [16] and Kumar et al. [17] using 2D crustal seismic velocity models and 2D gravity modeling by Mishra, [18], Verma and Banerjee [19], Sridhar and Tewari, [20] and Mishra et al. [21]. The high Bouguer gravity anomaly between Jabalpur and Mandla suggests localized uplift of SNSF and the presence of a magmatic body at different depths. Murty et al. [16] have concluded that the upper Vindhyans directly overlie the Archaean basement between Hirapur and Narsinghgarh. Between Narsinghgarh and Katangi, the Vindhyan basin consists of the upper and lower Vindhyans [22]. Narmada fault zone is divided into two parts, namely, Son-Narmada north fault (SNNF) and Son-Narmada south fault (SNSF). Using the basin morphology and drainage network, an attempt has been made to understand the role of geological structure in the evolution of drainage basin.

\section{Tectonic Setting and Stratigraphy of (SONATA)}

The Satpura range is bounded by Narmada graben in the north and the Tapi graben in the south. Seismic reflection and wide angle reflection data across the Son-Narmada lineament clearly bring out its graben character underneath the Deccan lavas in the west $[24,25]$. These demonstrate presence of a horst like feature between the north Narmada fault and the south Narmada fault in the eastern part [22] (Figures 1(a) and $1(\mathrm{~b})$ ). The $1300 \mathrm{~km}$ long Narmada river in central India flows through three major bedrock gorges separated by alluvial basins. In the downstream direction, these are the Marble Canyon near Jabalpur, Punasa Gorge near Khandwa, and Dhadgaon Gorge west of Barwani [26]. These horst like features are associated with a midcrustal and Moho upwarp, implying its formation as a result of deep seated tectonics in the Precambrian time [27]. The grabens exhibit high heat flow of $290 \pm 50 \mathrm{~mW}$ per $\mathrm{m}^{2}$ in the Tattapani-Jhor area in Narmada rift and $97-135 \mathrm{~mW} / \mathrm{m}^{2}$ at Salbardi in the Tapi valley [13]. The graben is continuing to subside along delimiting fault. The recent activity on the faults defining the graben is evident from abrupt eastward swing and reaches up to northerly flowing tributaries of the Narmada river along the foot of the alluvial scarp parallel to the graben fault. Various fault blocks and their alluvial cones are consequently sunken and tilted up to $300 \mathrm{~m}$ [15] in depth as seen in seismic profile [22] which shows that the basement-sediment contact is formed at $200-300 \mathrm{~m}$ depth. The Narmada-Tapi domain is thus a belt of tectonic resurgence where streams show deflection of channels as is evident from their longitudinal profiles (Figure 2). In the lower reaches of the Narmada, there was slow subsidence of the basin during the late Pleistocene time, followed by inversion of movement in the Holocene [11].

The SONATA zone in central Indian shield divides the Indian plate into two halves and has a long tectonic history dating back to the Archaean times [27] and trends in ENEWSW direction and is laterally traceable for more than $1000 \mathrm{~km}$ [11]. It demarcates the Peninsular India into two geologically distinct provinces: the Vindhyan-Bundelkhand province to the north and the Deccan province to the south. The Narmada and Tapi rivers throughout their course follow these tectonic trends that are also known as central Indian tectonic zone (CITZ) [12, 28-30]. The zone witnessed largescale tectonothermal events associated with large granitic intrusions around $2.5-2.2$ and $1.5-0.9 \mathrm{Ga}$ [12]. It was again reactivated during the Deccan volcanic eruption during Late Cretaceous-Palaeocene $[11,31]$. The region is crisscrossed by $\mathrm{E}-\mathrm{W}$-trending dykes, which were probably formed due to main centre of eruptive activity [32], and the zone is thermomechanically and seismically vulnerable in the framework of contemporary tectonism [32]. Seismic reflection and wide angle reflection data of Dixit et al. [25] reveal three Tertiary sedimentary subbasins: the Mehmadabad-Jambusar basin, the Jambusar-Kosamba basin, and the Kosamba-Bilimora basin. These basins are vertically offset relative to each other along high-angle faults, and the maximum depth $(\sim 9.5 \mathrm{~km})$ 
to the granitic/Proterozoic basement $\left(5.8-6.0 \mathrm{~km} \mathrm{~s}^{-1}\right)$ in the region occurs in the Jambusar-Broach area. Near-surface sedimentary rocks within the subbasins are underlain by Deccan Trap volcanics $\left(4.75-5.2 \mathrm{~km} \mathrm{~s}^{-1}\right)$, which have also been vertically offsetted [25]. The westward extension of this zone into the lower Narmada valley exhibits a less complex structural setting. In the lower Narmada basin, it is expressed as a single deep-seated fault (NSF) confirmed by the deep seismic sounding studies [25,33]. Seismic reflection studies have firmly established that the NSF is a normal fault in the subsurface and becomes markedly reverse near the surface [34]. Reactivation of the fault in Late Cretaceous led to the formation of a depositional basin in which marine Bagh beds were deposited [35]. The NSF remained tectonically active since then with continuous subsidence of the northern block, designated as the Broach block, which accommodated 6$7 \mathrm{~km}$ thick Cenozoic sediments in Cambay basin [11,35]. The Cenozoic sections within the SONATA zone shows offsetting of litho units [34]; however, the movements along this fault have not been unidirectional throughout. The general tendency of the basin to subside has been punctuated by phases of structural and tectonic inversion [34]. The N-Sdirected compressive stresses during the early Quaternary folded the Tertiary sediments into a broad syncline, the Broach syncline, in the rapidly subsiding northern block [34].

\section{Geomorphometric Analysis}

3.1. Methodology. It is well recognized that the commonly used geomorphometric indices of active tectonics are powerful tools to evaluate the relationship between tectonics and basin morphology to identify geologically recent deformations [36-38]. Calculation of the number of geomorphometric indices for a large region such as central peninsular India was made possible by the analysis of ASTER 1.5 arc second satellite data. The ASTER data have been found to be suitable for regional scale morphometric analysis [39, 40]. The Narmada river originates from Amarkantak at a height of 1068 m.a.s.l. (above sea level) and merges in gulf of Khambhat west of Bharuch. Longitudinal profile of Narmada river has been generated with the help of ASTER DEM to ascertain the role of major/minor structures in the evolution of valley landforms (Figure 2). For geomorphometry, four commonly used geomorphic indices of active tectonics such as stream length gradient index (SL), asymmetry factor (AF), transverse-topographic symmetry $(T)$, and valley floor height Ratio (Vf) have been used which are calculated for the different segments. These indices are considered powerful tools to evaluate the relationship between tectonics and basin morphology on the regional or basin scale and to identify geologically recent deformation $[36,40]$.

3.2. Stream Length Gradient Index (SL). The SL is used to infer stream power and rock erodibility [41] due to its sensitivity to disequilibrium state of channels due to tectonic

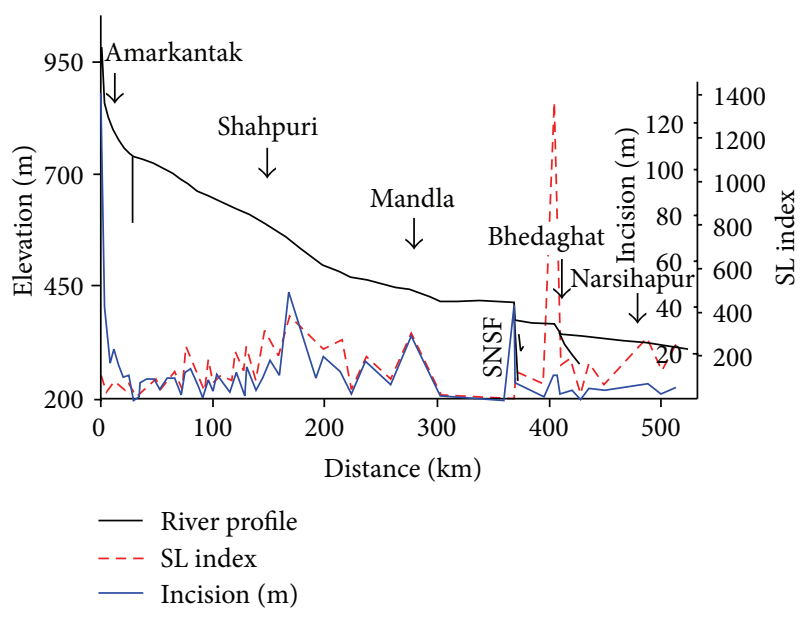

FIgURE 3: Longitudinal profile of Narmada river showing position of knick points at two places along the river. Changes in river gradient are marked by increase/decrease of SL index values as plotted by red brocken line. Solid blue line indicates bedrock depth incision along the longitudinal trace of river Narmada.

and climatic perturbation in the channel slope [38]. The gradient index is expressed as

$$
\mathrm{SL}=\left(\frac{\Delta H}{\Delta L}\right) \times L,
$$

where $\Delta H$ is the change in elevation of the reach, $\Delta L$ is the change in length of the reach, and $L$ is the total length of the channel from the point where the SL index is being calculated upstream to the highest point on the channel [41]. Abrupt changes in slope $(\Delta H / \Delta L)$ and the SL index have proved to be an excellent method to evaluate the ongoing processes of uplift of the underlying structures [42]. The SL index has been calculated all along the river profile which shows anomalous values in the vicinity of Shahpuri, Mandla, and Bhedaghat areas. The SL values range from 100 to 390 (between Shahpuri and Mandla) and from 100 to 1400 (between SNSF and Bhedaghat). The highest value (1400) is observed in vicinity of Bhedaghat area where the river passes through SNSF. In the SNSF zone, the river also shows high stream incision (Figure 3). The estimated incision depth in Amarkantak and downstream ranges between 10 and $120 \mathrm{~m}$. In Shahpuri and Mandla area, the incision depth ranges between 5 and $50 \mathrm{~m}$, whereas the incision depth of SNSF zone ranges between 5 and $40 \mathrm{~m}$. Sudden increase of SL values implies differential uplift.

3.3. Basin Asymmetry (AF). The outcome of stream length analysis is supported by evidence gathered from basin asymmetric factor. The asymmetry factor was developed to detect tectonic tilt by using the formula

$$
\mathrm{AF}=100\left(\frac{\mathrm{Ar}}{\mathrm{At}}\right),
$$

where $\mathrm{AF}$ is the asymmetry factor, $\mathrm{Ar}$ is the area of the basin to the right, and At is total area of basin. The asymmetry 


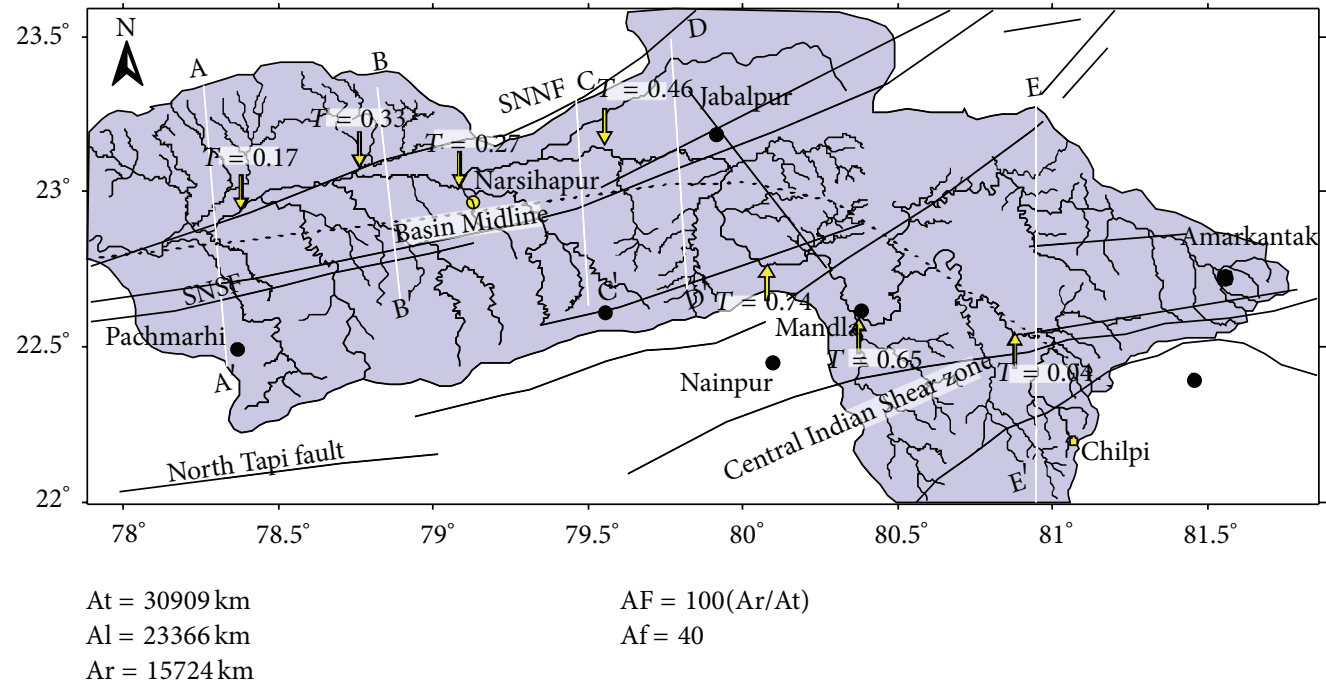

FIGURE 4: Drainage map of upper Narmada river basin showing calculated values of basin asymmetry (AF), topographic symmetric factor $(T)$; solid white lines $\left(\mathrm{A}-\mathrm{A}^{\prime}, \mathrm{B}-\mathrm{B}^{\prime}, \mathrm{C}-\mathrm{C}^{\prime}, \mathrm{D}-\mathrm{D}^{\prime}\right.$, and $\left.\mathrm{E}-\mathrm{E}^{\prime}\right)$ indicate cross-profile directions.

factor of 40 points to regional tectonic tilt towards the NNW direction (Figure 4). Tilting of topography may be associated with activity of ENE-WSW trending SNF zone.

3.4. Transverse Topographic Symmetry (T). Transverse topographic symmetry is another quantitative parameter to evaluate tectonic tilt of basin; it is expressed as

$$
T=\frac{\mathrm{Da}}{\mathrm{Dd}}
$$

where $\mathrm{Da}$ is the distance from midline of the drainage basin to the midline of the active meander belt. Dd is the distance from the basin midline to basin divide. In general, the value of $T$ ranges from 0 to $1 . T=0$ implies a perfectly symmetrical basin and $T=1$ indicates a perfectly asymmetrical one [43]. Tectonic deformation impacts the drainage of that area through changes in the channel slope [44]. In present study, the observed value of $T$ for Narmada river ranges from 0.04 to 0.65 for (SNSF) implying ground tilting of river basins (Figure 4).

3.5. Valley Floor Height and Width Ratio (Vf). Valley floor height and width ratio (Vf) is defined as an index of the form shape of the valley; indicates whether the river is actively downcutting and incising [36] by

$$
\mathrm{Vf}=\frac{2 \mathrm{Vfw}}{((\text { Eld }- \text { Esc })+(\text { Erd }- \text { Esc }))},
$$

where Vf is the valley floor width-to height ratio, Vfw is the width of the valley floor, Eld and Erd are elevations of the left and right valley divides, respectively, and Esc is the elevation of the valley floor. The downcutting of valley is commonly associated with the higher rate of uplift in tectonically active areas. The small values of Vf $(<1)$ reflect deep narrow, V shaped valleys which are commonly associated with relative rapid uplift [40]. In contrast, high values $(>1)$ are markers of wide open valleys in the regions of minimal uplift rates [37]. The index is used to evaluate tectonic activity along front impediment faults along the Son-Narmada south fault. We observed lower value of Vf towards the eastern limit of Jabalpur and comparatively higher value towards west which reflects that the eastern margin of Jabalpur is tectonically more active than the western limit. Near Jabalpur, Narsinghpur, and Hoshangabad, the Vf values are 24.31, 24.6 and 25.65 which are associated with broad open valleys indicating lateral erosion due to stability of base level and less tectonic activity. Near Amarkantak and Mandla, the obtained Vf ratios are 12.55 and 14.52 which are associated with intense tectonic perturbation in Quaternary time.

The elevation difference in N-S profiles shows that the southern block of basin is uplifted and the entire topography is tilted towards NNW direction (Figure 5). The southern block of basin is much elevated along the SNF and has rugged topography as compared to the northern block. The southern block is devoid of any Quaternary and indicates continuous uplift and erosion of the bed rocks. The presence of Quaternary deposits towards the north of basin suggests subsidence of the northern block relative to differential uplift of the southern block.

Neotectonic activity in Jabalpur area includes seismic activity and development of young geomorphic features. These features include development of strath terraces with huge Pleistocene (9-40 Ka) alluvial cover all along the river course and formation of gorges ( $100 \mathrm{~m}$ deep) with steep vertical wall and development of $10 \mathrm{~m}$ high waterfall [26]. Incision and steepening of Narmada river floor with vertical wall probably formed due to vertical tectonic movement of Narmada faults during 60-40 ka [26].

3.6. Seismicity and GPS Observations. Historical and instrumental records indicate that the compressive stresses still 


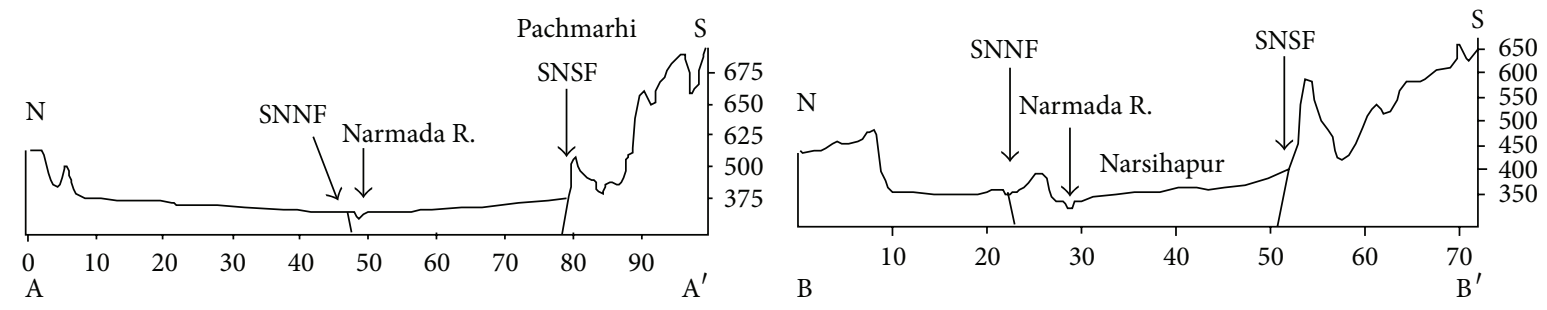

(a)

(b)
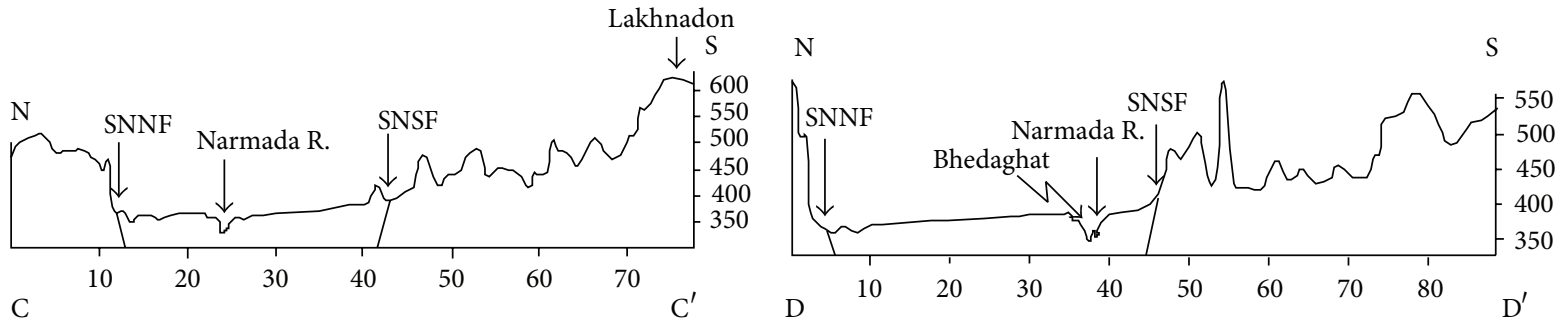

(c)

(d)

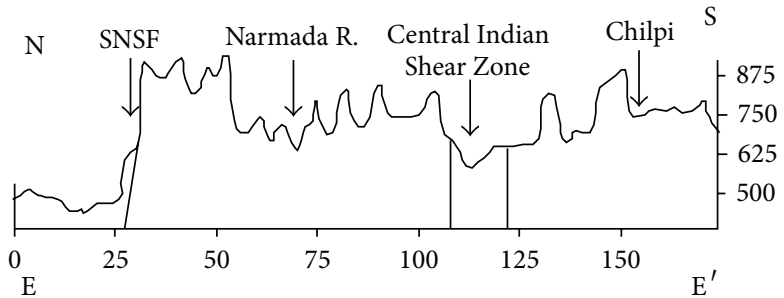

(e)

Figure 5: Cross-valley profiles have been constructed along the lines A- $\mathrm{A}^{\prime}, \mathrm{B}-\mathrm{B}^{\prime}, \mathrm{C}-\mathrm{C}^{\prime}, \mathrm{D}-\mathrm{D}^{\prime}$, and E- $\mathrm{E}^{\prime}$ to show variation of topography towards north and south directions. The elevation difference in N-S profiles shows that the southern block of basin is uplifted.

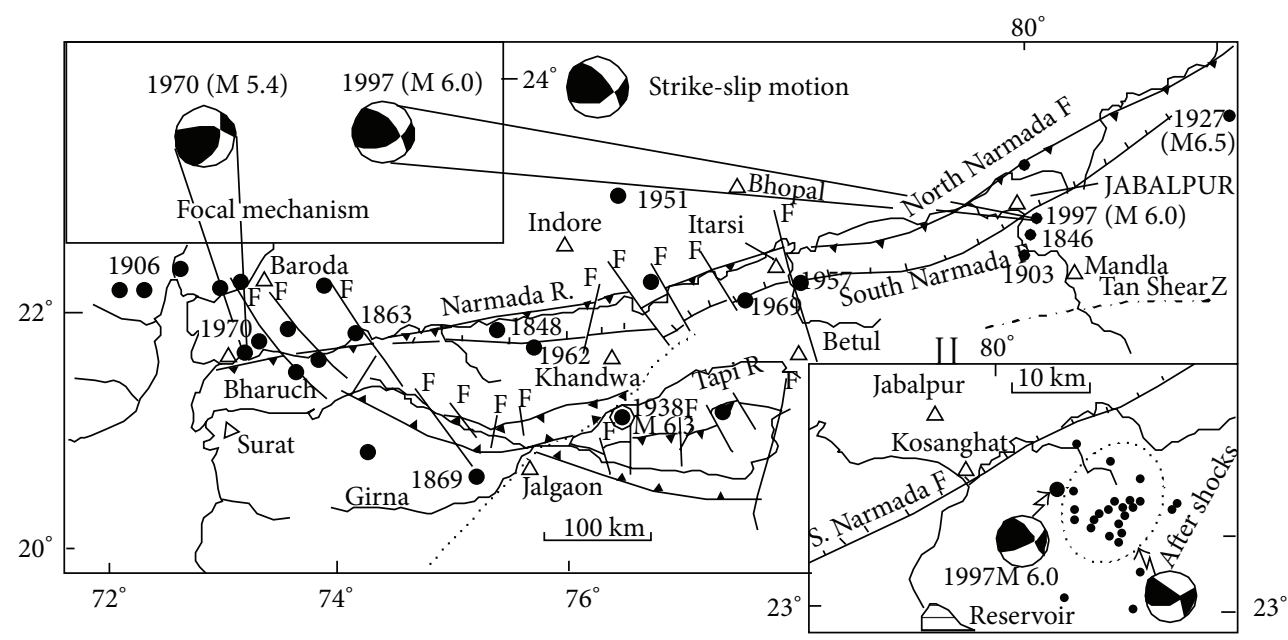

FIGURE 6: Tectonic map of SONATA shows epicentral distribution of earthquakes $[15,48,49]$. The index beach ball shows thrust faulting with strike-slip component.

continue to accumulate along the fault zone due to continued northward movement of the Indian plate. This is evidenced by the fault solution studies of the earthquakes at Broach (23 March 1970) and Jabalpur (22 May 1997) (Figures 1(a) and 6), which suggest a thrusting movement [45-47]. Results obtained from geomorphometric observations were validated and crosschecked with the results obtained from seismic and GPS observations of various workers. The ongoing movements are manifest in recurrent seismicity in upper Narmada catchment of central India. The enhanced earthquake activity 
in SONATA zone occurred during the period 1876 to 1993 which includes 23 March 1970 Bharuch earthquake of Mw 5.4, 1927 event of Mw 6.5 that occurred southwest of Rewa, 1938 earthquake of Mw 6.3 near Khandwa, 1945 earthquake of Mw 5.7 in Navagam, and the 1997 Jabalpur earthquake of Mw 6.0 (Figure 6). The 22 May 1997 Jabalpur earthquake occurred at a depth of $36 \pm 4 \mathrm{~km}$ along an ENE-WSE trending fault [48]. Fault plane solution indicates reverse faulting with a component of left lateral strike-slip motion [49]. This is the first significant strong earthquake that was recorded by the broadband stations of the national network, and the focal depth was well estimated using the depth phases [50]. It is observed that the earthquake was associated with the Narmada rift and was of deep crustal source. The seismic crosssection of , the main shock and aftershocks by Kayal [49], indicates that the south dipping Narmada south fault (NSF), the southern margin fault of the Narmada rift basin, was activated by reverse faulting and the earthquakes occurred at depth of $35 \mathrm{~km}$ and up. The seismic pattern in upper Narmada catchments is directly correlated with geomorphic indices suggesting that the eastern limit of upper Narmada river is more active than western limit. Occurrence of 1846, 1903, 1927, and 1997 tremors in and around the eastern limit of Jabalpur was correlated with lines of evidence gathered from geomorphic datasets. The observations by Kayal [49] further suggest that the rift basin boundary faults are mantle reaching; these faults are developed in tensional regime in the geological past and are now under compressive stress due to the NNE movement of the Indian plate [51].

Occurrence of seismicity in Son-Narmada fault zone was further allied with GPS observation of Banerjee et al. [52] and Apel et al. [51] (Figure 7). The velocity model of Apel et al. [51] shows northward motion in the south and southward motion in the north, across the SNF zone as indicated by black vectors in Figure 7, indicateing that the central part of India is under contraction [52]. The Son-Narmada lineament zone separates the Indian subcontinent into two blocks [51], for example, north Indian and south Indian blocks showing $4 \mathrm{~mm} / \mathrm{yr}$ contraction in the east to $1 \mathrm{~mm} / \mathrm{yr}$ in the west which suggests N-S contraction in central India along SNF (Figure 7). The Narmada-Son lineament through central India shows high heat flow and strain rate estimated from seismicity which is larger than that in many stable continental regions and suggests a concentration of intraplate deformation [53]. It is possible that the seismicity in the region is also enhanced by a thinned and weakened lithosphere due to passive-margin normal faulting in the Cretaceous $[6,25]$ and by heating from the plume head responsible for the late Cretaceous Deccan flood basalts [54, 55].

\section{Discussion}

Increase of river gradient index in two places in and around Jabalpur indicates vertical uplift due to N-S compression along SNF zone. Valley floor height and width ratio and basin asymmetric facture suggest that the entire basin is tilted towards NNW direction. The geomorphometric database

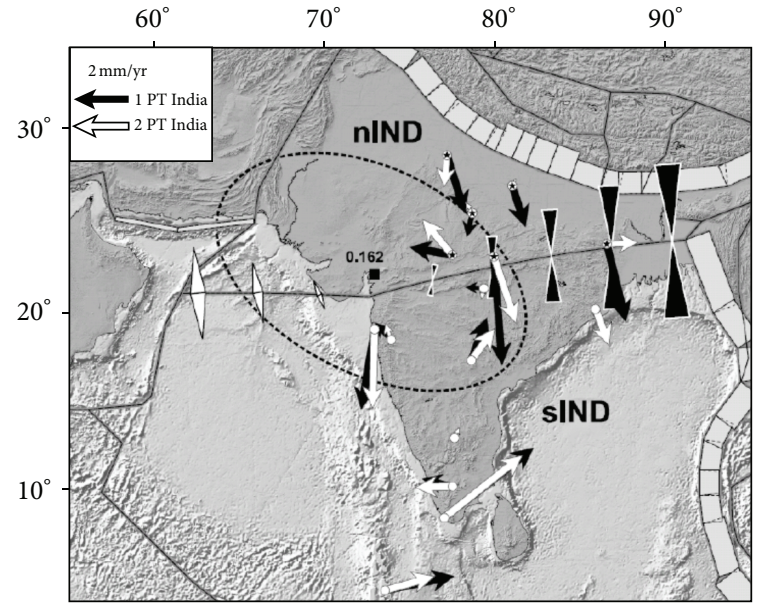

Figure 7: Residual velocities shown for the 1-block model (black vectors) and 2-block India model (white vectors). Separation of the Indian block (grey line) is along the Narmada-Son Lineament in Central India [51]. The relative pole of rotation for the 2-block India model is shown in the west with a 20 sigma error ellipse. The rotation rate of $0.162 \mathrm{deg} / \mathrm{My}$ predicts contraction along the Narmada-Son line from $5 \mathrm{~mm} / \mathrm{yr}$ in the east to $0 \mathrm{~mm} / \mathrm{yr}$ near the pole in the west (black triangles). Extensional rates in Arabian Sea are shown by White triangles [51].

and satellite data interpretation clearly suggest that the SonNarmada south fault was activated during the Quaternary time. Various tectonically induced landforms were formed all along the Narmada river. Shifting of river channel (near Amarkantak) and waterfall; formation of gorge with nearly vertical wall in and around Bhedaghat, and development of strath terraces are common landform features which were formed due to movement along SNF. These observations suggest strain accumulation in the Son-Narmada fault zone.

The geomagnetic field variation and GPS observations also suggested strain accumulation in the region. A high geomagnetic anomaly field variation in Narmada river region ranging between \pm 0.06 and $\pm 9.54 \mathrm{nT}$ indicates accumulation of stress within the SNF zone $[1,51]$. On the basis of aeromagnetic database, Anand and Rajaram [56] believe that the two ENE-WSW and NW-SE trending tectonic features were reactivated in Quaternary time. GPS observations of Apel et al. [51] suggest that the strain is accumulating beneath the Son-Narmada south fault. The accumulation of strain beneath this zone probably may cause strong earthquakes in future.

The morphometric indices and geomorphological observations in the Narmada river suggest the role of seismicity in the evolution of fluvial landform. Conventionally, tilting of the basin is attributed to tectonic control. The Narmada river is occupied by the rocks belonging to Vindhyan and Satpura towards upper reaches and Deccan basalt towards lower reaches. The river system is controlled by two parallel faults (SNNF and SNSF). The ongoing tectonic uplift along preexisting faults is conventionally examined through abrupt changes in river gradient. The observed SL values between Shahpuri and Mandla ((100-390) and (100-1400)) in and 
around Jabalpur suggest vertical tectonic processes along SNSF. The basin is tilting towards NNW due to tectonic movement along SNSF zone (Figure 3). Towards the upper reaches the river shows southwest migrations where $T$ ranges between 0.04 and 0.65 . The lower reaches show migration of river towards NNW which is supported by observed $T$ (0.170.46). Migration of river can be assigned to low resistance bedrock or tectonic uplift along SNSF (Figure 4). The Vf value for upper reaches ranges between 12.55 and 14.52, and towards lower reaches, the Vf values are 24.31, 24.6, and 25.65. These abnormal changes in Vf towards upper and lower reaches could be associated with intense tectonic uplift. Further morphometric indices and geomorphic anomalies (water fall, gorges, etc.) together indicate that the terrain is active.

\section{Conclusion}

(i) Morphometric indices and the drainage pattern indicate that Shahpuri-Mandla and Jabalpur-Narsihapur segments in the SNF zone are active and showing enhanced uplift in Narmada river basin.

(ii) Geodetic observations of Apel et al. [51] suggest that the SNSF zone is major stress accumulation zone in SONATA zone.

(iii) Seismicity pattern and occurrence of moderate earthquakes in the region implie that the area has potential for another moderate earthquake in future.

\section{Acknowledgments}

The study was supported by Gujarat State Disaster Management Authority. We thank the anonymous referees for their critical reviews and constructive comments which helped to improve the quality of the manuscript.

\section{References}

[1] S. Y. Waghmare and L. Carlo, "Geomagnetic Investivation in the seismoactive area of Narmada-Son lineament, Central India," Journal of Indian Geophysical Union, vol. 12, no. 1, pp. 1-10, 2008.

[2] Geological Survey of India, Projet Crumansonata: Geoscientific Studies of the Son-Narmada-Tapi Lineament Zone, 1995.

[3] W. D. West, “The line of Narmada-Valley, Current Science, vol. 31, pp. 143-144, 1962.

[4] J. B. Auden, "Geological discussion of the Satpura hypothesis," Proceedings of the National Institute of Sciences of India, vol. 15, pp. 315-340, 1949.

[5] M. S. Krishnan and J. Swaminathan, "The great Vindhyan basin of northern India," Journal of the Geological Society of India, vol. 1, pp. 10-30, 1959.

[6] S. Biswas, I. Coutand, D. Grujic, C. Hager, D. Stöckli, and B. Grasemann, "Exhumation and uplift of the Shillong plateau and its influence on the eastern Himalayas: new constraints from apatite and zircon (uth-[sm])/he and apatite fission track analyses," Tectonics, vol. 26, no. 6, 2007.

[7] M. N. Qureshy, "Geophysical and Landsat lineament mapping-an approach illustrated from West-Central and
South India," Photogrammetria, vol. 37, no. 3-5, pp. 161-184, 1982.

[8] A. K. Jain, N. Annup, and D. C. Singhal, "Crustal evolution of the Narmada-Son lineament and associated shear zones of the Indian lithosphere," Indian Journal of Earth Science (CEISM Seminar), pp. 125-148, 1984.

[9] D. M. Maurya, R. Rachna, and L. S. Chamyal, "Seismically induced deformational structures (seismites) from the mid-late Holocene terraces, lower mahi valley, Gujarat," Journal of the Geological Society of India, vol. 51, no. 6, pp. 755-758, 1998.

[10] D. M. Maurya, R. Rachna, and L. S. Chamyal, "History of tectonic evolution of Gujarat alluvial plains, western India during Quaternary: a review," Journal of the Geological Society of India, vol. 55, no. 4, pp. 343-366, 2000.

[11] L. S. Chamyal, D. M. Maurya, S. Bhandari, and R. Raj, "Late Quaternary geomorphic evolution of the lower Narmada valley, Western India: implications for neotectonic activity along the Narmada-Son Fault," Geomorphology, vol. 46, no. 3-4, pp. 177202, 2002.

[12] S. K. Acharyya and A. Roy, "Tectonothermal history of the central Indian tectonic zone and reactivation of major faults/shear zones," Journal of the Geological Society of India, vol. 55, no. 3, pp. 239-256, 2000.

[13] R. Shanker, Geothermal Atlas of India, Geological Survey of India, Kolkata, India, 1991.

[14] D. C. Mishra and P. Kumar, "Characteristic of faults associated with Narmada-Son lineament and rock types of Jabalpur section," Current Science, vol. 75, pp. 308-310, 1998.

[15] K. S. Valdiya, The Making of Indian Geodynamic Evolution, Macmillian Publication House, New Delhi, India, 2010.

[16] A. S. N. Murty, D. M. Mall, P. R. K. Murty, and P. R. Reddy, “Twodimensional crustal velocity structure along Hirapur-Mandla profile from seismic refraction and wide-angle reflection data," Pure and Applied Geophysics, vol. 152, no. 2, pp. 247-266, 1998.

[17] P. Kumar, H. C. Tewari, and G. Khandekar, "An anomalous highvelocity layer at shallow crustal depths in the Narmada zone, India," Geophysical Journal International, vol. 142, no. 1, pp. 95107, 2000.

[18] D. C. Mishra, "Mid-continent gravity "high" of central India and the Gondwana tectonics," Tectonophysics, vol. 212, no. 1-2, pp. 153-161, 1992.

[19] R. K. Verma and P. Banerjee, "Nature of continental crust along the Narmada-Son lineament inferred from gravity and deep seismic sounding data," Tectonophysics, vol. 202, no. 2-4, pp. 375-397, 1992.

[20] A. R. Sridhar and H. C. Tewari, "Existence of a sedimentary graben in the western part of Narmada Zone: seismic evidence," Journal of Geodynamics, vol. 31, no. 1, pp. 19-31, 2001.

[21] D. C. Mishra, K. Arora, and V. M. Tiwari, "Gravity anomalies and associated tectonic features over the Indian Peninsular shield and adjoining ocean basins," Tectonophysics, vol. 379, no. 1-4, pp. 61-76, 2004.

[22] H. C. Tewari, A. S. N. Murty, P. Kumar, and A. R. Sridhar, "A tectonic model of the Narmada region," Current Science, vol. 80, no. 7, pp. 873-878, 2001.

[23] V.S. Krishnaswamy and K. R. Raghunandan, "The Satpura uplift and the palaeoclimate of the Holocene and auxiliary evidence from the Valmiki Ramayana," Journal of the Geological Society of India, vol. 66, no. 2, pp. 161-170, 2005.

[24] K. L. Kaila, P. R. K. Murty, D. M. Mall, M. M. Dixit, and D. Sarkar, "Deep seismic soundings along Hirapur-Mandla profile, 
central India," Geophysical Journal of the Royal Astronomical Society, vol. 89, no. 1, pp. 399-404, 1987.

[25] M. M. Dixit, H. C. Tewari, and C. V. Rao, "Two-dimensional velocity model of the crust beneath the South Cambay Basin, India from refraction and wide-angle reflection data," Geophysical Journal International, vol. 181, no. 2, pp. 635-652, 2010.

[26] A. Gupta, V. S. Kale, L. A. Owen, and A. K. Singhvi, "Late Quaternary bedrock incision in the Narmada river at Dardi Falls," Current Science, vol. 93, no. 4, pp. 564-567, 2007.

[27] R. Shanker, "Thermal and crustal structure of "SONATA". A zone of mid continental rifting in Indian shield," Journal of the Geological Society of India, vol. 37, no. 3, pp. 211-220, 1991.

[28] V. D. Choubey, "Narmada-Son lineament, India," Nature, vol. 232, pp. 38-40, 1971.

[29] B. P. Radhakrishna and M. Ramakrishnan, "ArchaeanProterozoic boundary in India," Journal of the Geological Society of India, vol. 32, no. 4, pp. 263-278, 1988.

[30] S. C. Jain, K. K. K. Nair, and D. B. Yedekar, "Geology of the SonNarmada-Tapi lineament zone in Central India. Geoscientific studies of the Son-Narmada-Tapi lineament zone," in Project Crumansonata, vol. 10 of Special Publication, pp. 1-154, Geological Survey of India, 1995.

[31] B. N. P. Agarwal, L. K. Das, K. Chakraborty, and C. H. Sivaji, "Analysis of the Bouguer anomaly over central India: a regional perspective," Journal of the Geological Society of India, vol. 31, pp. 469-493, 1995.

[32] S. Bhattacharji, N. Chatterjee, and J. M. Wampler, "Zones of Narmada-Tapi rift reactivation and Deccan volcanism: geochronological and geochemical evidence," in Deccan Basalts, S. S. Deshmukh and K. K. K. Nair, Eds., pp. 329-340, Gondwana Geological Society, Nagpur, India, 1996.

[33] K. L. Kaila, V. G. Krishna, and D. Mall, "Crustal structure along Mehmadabad-Billimora profile in the Cambay basin, India, from deep seismic soundings," Tectonophysics, vol. 76, no. 1-2, pp. 99-130, 1981.

[34] T. K. Roy, "Structural styles in southern Cambay basin India and role of Narmada geofracture in the formation of giant hydrocarbon accumulation," Bulletin of the Oil and Natural Gas Commission, vol. 27, pp. 15-38, 1990.

[35] S. K. Biswas, "Regional tectonic framework, structure and evolution of the western marginal basins of India," Tectonophysics, vol. 135, no. 4, pp. 307-327, 1987.

[36] W. Bull and L. Mcfadden, "Tectonic geomorphology north and south of the Garlock Fault California," in Geomorphology in Arid Region, D. O. Doehring, Ed., pp. 115-138, State University of New York, Binghamton, NY, USA, 1977.

[37] E. A. Keller and N. Pinter, Active Tectonics, Prentice Hall, Upper Seddle River, NJ, USA, 1996.

[38] D. W. Burbank and R. S. Anderson, Tectonic Geomorphology, Blackwell Science, 2001.

[39] D. Harbor and Y. Gunnell, "A long-strike escarpment heterogeneity of the Western Ghats: a synthesis of drainage and topography using digital morphometric tools," Journal of the Geological Society of India, vol. 70, no. 3, pp. 411-426, 2007.

[40] V. S. Kale and N. Shejwalkar, "Uplift along the western margin of the Deccan Basalt Province: is there any geomorphometric evidence?" Journal of Earth System Science, vol. 117, no. 6, pp. 959-971, 2008.

[41] J. T. Hack, "Stream profile analysis and stream gradient index," Journal of Research of the U.S. Geological Survey, vol. 1, pp. 421429, 1973.
[42] L. Seeber and V. Gornitz, "River profiles along the Himalayan arc as indicators of active tectonics," Tectonophysics, vol. 92, no. 4, pp. 335-367, 1983.

[43] P. W. Hare and T. W. Gardner, "Geomorphic indicators of vertical neotectonism along convergent plate margins, Nicoa Peninsula, Costa Rica," in Tectonic Geomorphology: Proceedings of the 15th Annual Binghamton Geomorphology Symposium, International Series, vol. 15, pp. 75-104, 1985.

[44] V. Jain and R. Sinha, "Response of active tectonics on the Alluvial Baghmati river, Himalayan foreland basin, eastern India," Geomorphology, vol. 70, no. 3-4, pp. 339-356, 2005.

[45] H. K. Gupta, I. Mohan, and H. Narain, “The Broach earthquake of March 23, 1970," Bulletin of the Seismological Society of America, vol. 62, pp. 47-61, 1972.

[46] H. K. Gupta, R. K. Chadha, M. N. Rao et al., "The Jabalpur earthquake of May 22, 1997," Journal of the Geological Society of India, vol. 50, no. 1, pp. 85-91, 1997.

[47] U. Chandra, "Earthquakes of peninsular India: a seismotectonics study," Bulletin of the Seismological Society of America, vol. 65, pp. 1387-1413, 1977.

[48] K. Rajendran and C. P. Rajendran, "Characteristics of the 1997 Jabalpur earthquake and their bearing on its mechanism," Current Science, vol. 74, no. 2, pp. 168-174, 1998.

[49] J. R. Kayal, "Seismotectonic study of the two recent SCR earthquakes in central India," Journal of the Geological Society of India, vol. 55, no. 2, pp. 123-138, 2000.

[50] S. N. Bhattacharya, A. K. Ghose, G. Suresh, P. R. Baidya, and R. C. Saxena, "Source parameters of Jabalpur earthquake of May 22, 1997," Current Science, vol. 73, no. 10, pp. 855-863, 1997.

[51] E. V. Apel, R. Burgmann, and P. Banerjee, "Indian plate motion, deformation, and plate boundary interactions," Geophysical Journal International. In press.

[52] P. Banerjee, R. Bürgmann, B. Nagarajan, and E. Apel, "Intraplate deformation of the Indian subcontinent," Geophysical Research Letters, vol. 35, no. 18, 2008.

[53] B. R. Rao, "Historical seismicity and deformation rates in the Indian peninsular shield," Journal of Seismology, vol. 4, no. 3, pp. 247-258, 2000.

[54] B. L. N. Kennett and S. Widiyantoro, "A low seismic wavespeed anomaly beneath northwestern India: a seismic signature of the Deccan plume?" Earth and Planetary Science Letters, vol. 165, no. 1, pp. 145-155, 1999.

[55] D. V. Chandrasekhar, R. Bürgmann, C. D. Reddy, P. S. Sunil, and D. A. Schmidt, "Weak mantle in NW India probed by geodetic measurements following the 2001 Bhuj earthquake," Earth and Planetary Science Letters, vol. 280, no. 1-4, pp. 229-235, 2009.

[56] S. P. Anand and M. Rajaram, "Crustal structure of NarmadaSon Lineament: an aeromagnetic perspective," Earth, Planets and Space, vol. 56, no. 5, pp. 9-12, 2004. 

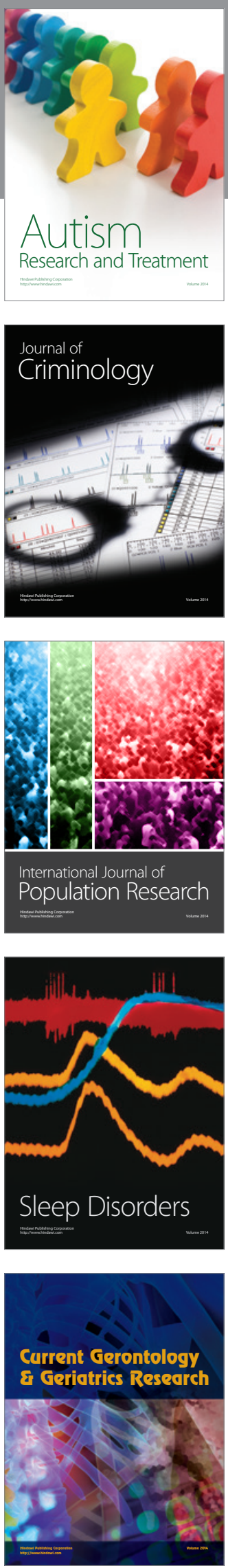
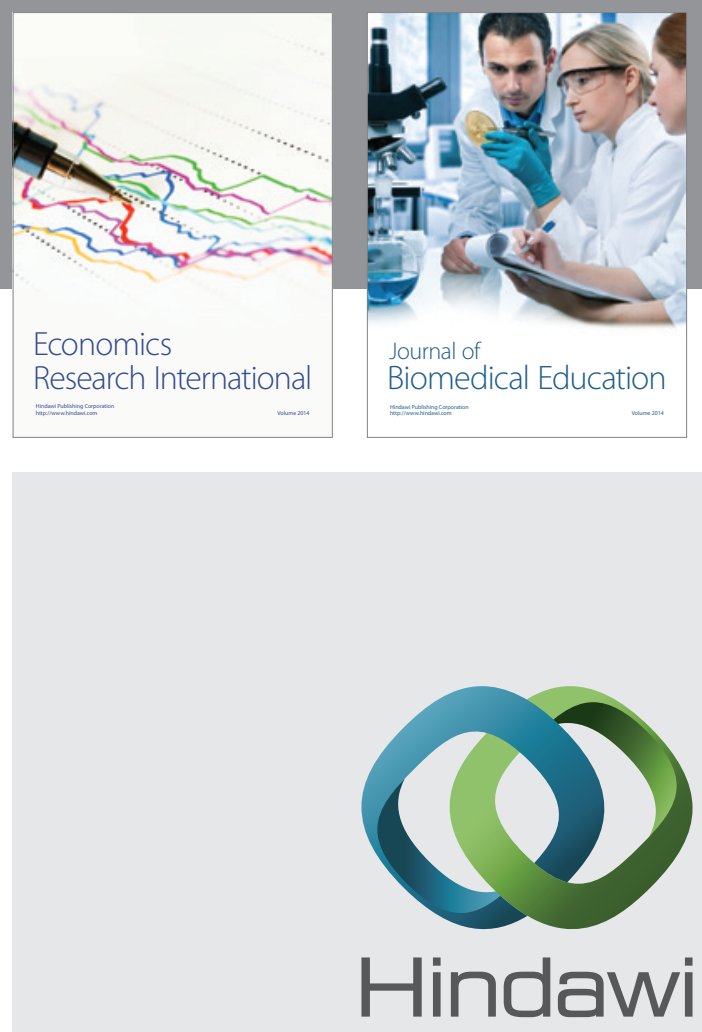

Submit your manuscripts at

http://www.hindawi.com
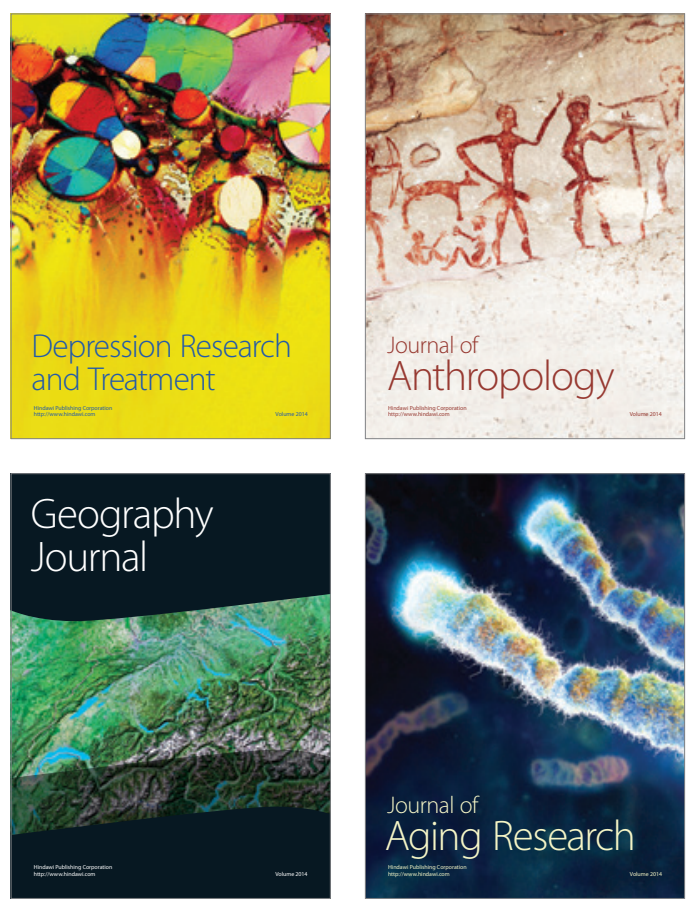
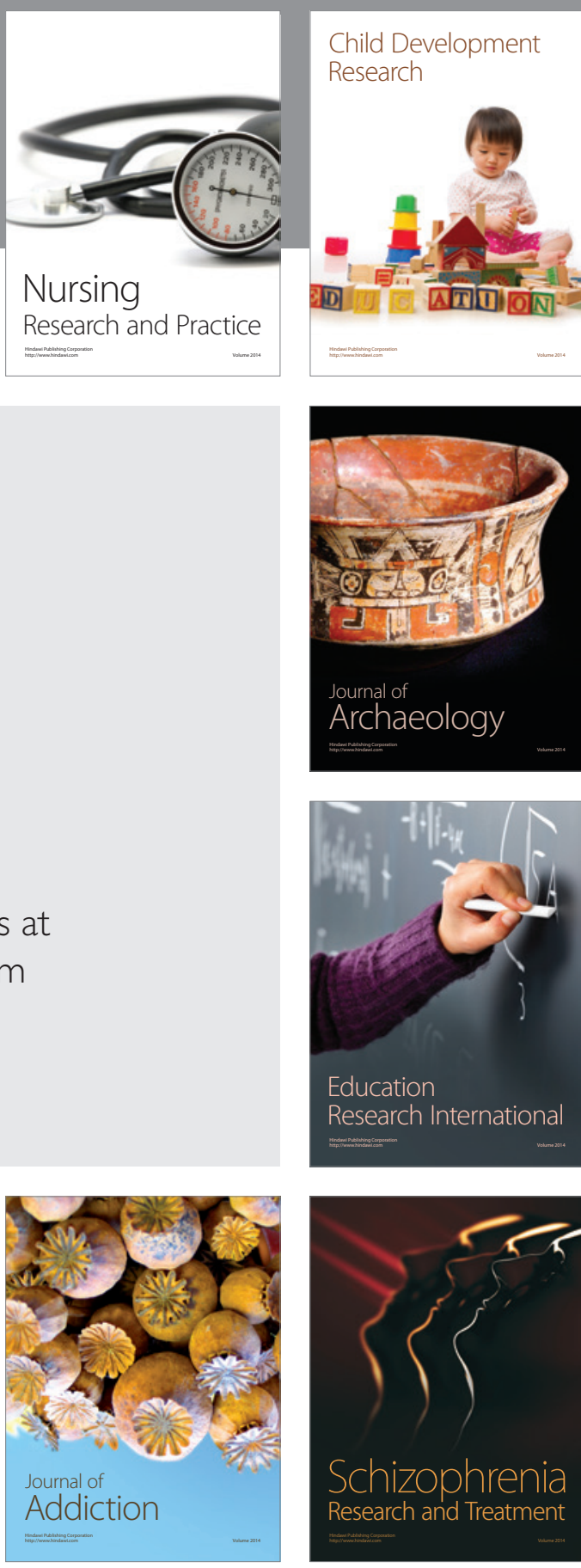

(D)
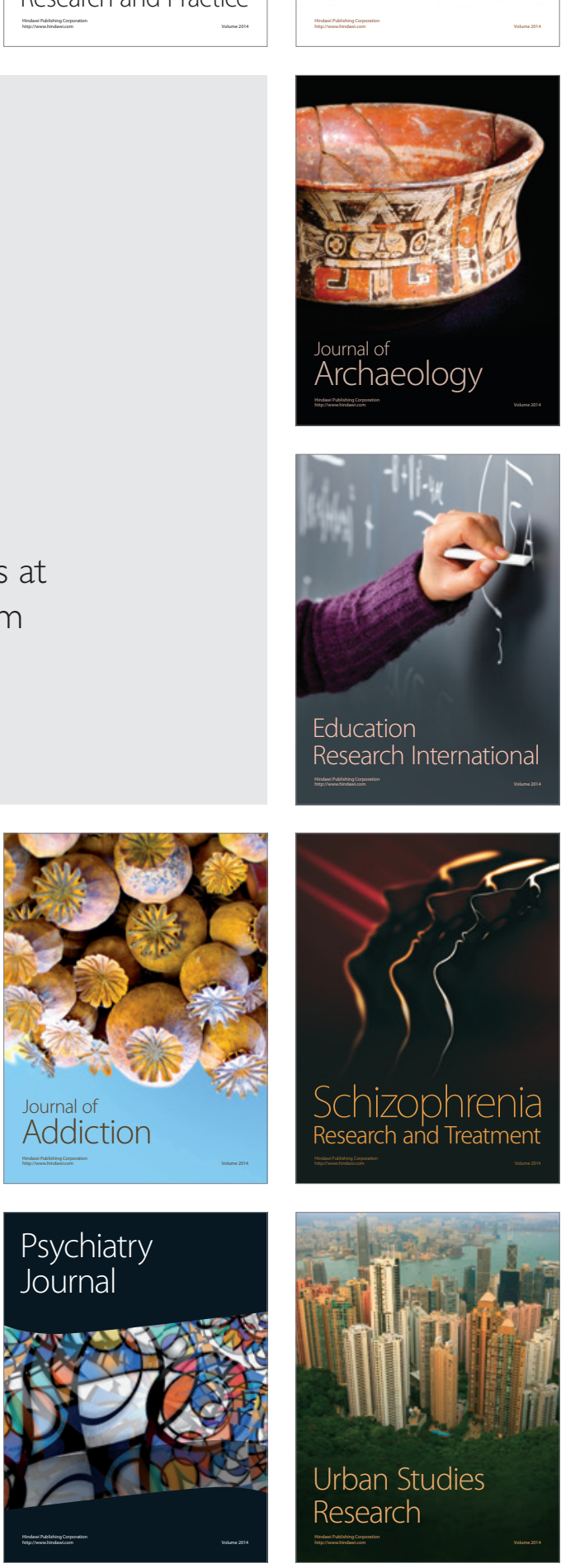